\title{
Biodiversity of Coreoidea and Pentatomidae (Heteroptera) from Atlantic forest protected areas. Insights into their conservation.
}

\author{
GIMENA DELLAPÉ ${ }^{1}$, KARINE D. COLPO ${ }^{2}$, MARÍA C. MELO ${ }^{1}$, SARA \\ I. MONTEMAYOR ${ }^{1}$ and PABLO M. DELLAPÉ ${ }^{1}$ \\ ${ }^{1}$ Universidad Nacional de La Plata, CONICET, División Entomología, Museo de La \\ Plata, Paseo del Bosque s/n, La Plata, Buenos Aires, Argentina \\ ${ }^{2}$ Instituto de Limnología Dr. Raúl A. Ringuelet - ILPLA (CONICET - UNLP), Boulevard \\ 120, Casco Urbano, 1900, La Plata, Buenos Aires, Argentina
}

Manuscript received on June 6, 2016; accepted for publication on August 13, 2016

\begin{abstract}
Although the majority of threatened species are likely to be tropical insects, knowledge of the diversity, ecological role and impact of insect biodiversity loss on ecosystem processes is very limited. Specimens belonging to four families of Heteroptera: Pentatomidae, Coreidae, Alydidae and Rhopalidae, were collected from a protected area in the Paraná Forest, the largest ecoregion of the Atlantic Forest, in Argentina. The assemblages were characterized and the biodiversity estimated, and they were compared with the assemblages found in five other protected areas in the Brazilian Atlantic Forest. In our study area, Pentatomidae had the greatest richness and diversity; Coreidae was the second most diverse family, with highest sampling deficit, highest percentage of singletons, and lowest inventory completeness; and Rhopalidae was the best sampled family with asymptotic rarefaction curves. We explored the application of the Species Conservation Importance index, following four criteria, to evaluate the relative importance of the pentatomid species studied and its usefulness for assigning conservation values to areas. We found similar Site Conservation Values among the six areas and noted that the use of criteria was limited by the lack of information, being crucial to increase the knowledge of most of the species.
\end{abstract}

Key words: Hemiptera, insects, conservation, diversity, Paraná Forest, South American Atlantic Forest.

\section{INTRODUCTION}

Tropical forests are characterized by extraordinarily high but poorly inventoried insect diversity. Since most terrestrial diversity occurs in the tropics, and more than half of this diversity is represented by insects, in addition to the fact that the most threatened habitats are in the tropics, the majority of

Correspondence to: Pablo Matías Dellapé

E-mail: pdellape@ffcnym.unlp.edu.ar endangered species are likely to be tropical insects (Lewis and Basset 2007). The relationship between biodiversity and ecosystem function provides a primary justification for conservation, but despite its importance, the study of the biodiversity of most protected areas has focused on vertebrates, and knowledge of the diversity, ecological role and impact of insect biodiversity loss on ecosystem processes is very limited (New 2012). Managing 
and preserving protected areas requires knowledge of their biodiversity.

The South American Atlantic Forest, which extends from the Atlantic coast of Brazil, and west into smaller, inland areas of Paraguay and Argentina, is a complex of ecoregions considered to be a biodiversity hotspot (Myers et al. 2000, Mittermeier et al. 2004). It is one of the largest and most threatened tropical rainforests in the world, with only $12.9 \%$ of its original extension remaining (Tabarelli et al. 2010).

Although the Atlantic Forest is highly fragmented, it is still one of the most diversified ecosystems on Earth, containing 7\% of the world's species (Cullen et al. 2001), including thousands of endemisms (Tabarelli et al. 2010). Its conservation is key to maintaining the species assemblages, where evolutionary and ecological processes proceed unabated (Galindo-Leal and Câmara 2003, Giraudo et al. 2003, 2008, Dellapé P et al. 2015).

The largest ecoregion of the Atlantic Forest is the Paraná Forest, which extends from the western slopes of the Serra do Mar in Brazil, to eastern Paraguay and the province of Misiones in Argentina (Di Bitetti et al. 2003). It includes one of the largest Atlantic Forest remnants, ca. 10,000 km², covering most of Misiones Province in Argentina (GalindoLeal and Câmara 2003, Giraudo et al. 2003). The Paraná Forest of northern Argentina still retains $38.7 \%$ of its original cover (Chebez and Hilgert 2003).

There are few inventories of certain insect taxa for a limited number of protected areas of the Argentinean Paraná Forest (Mazzucconi et al. 2009, Campos et al. 2011, Manzo et al. 2014). For terrestrial Heteroptera, the only available inventory was recently published from Parque Provincial Moconá and includes seventeen families of terrestrial true bugs (Dellapé P et al. 2015).

In this paper we selected four families of terrestrial Heteroptera: Pentatomidae, Coreidae, Alydidae and Rhopalidae, of which the latter three constitute the superfamily Coreoidea. Specimens were collected in a protected area of the Paraná Forest in Argentina. This study aims to characterize the assemblages, estimate their biodiversity, and compare our results with the assemblages found in five other protected areas located in the Brazilian Atlantic Forest. We also explored the application of the Species Conservation Importance index and Site Conservation Values proposed by Halmy and Salem (2015) to evaluate the relative importance of the species studied and its usefulness for assigning conservation values to areas.

\section{MATERIALS AND METHODS}

\section{STUDY AREA}

The specimens were collected in Parque Provincial Moconá, located in Misiones Province, in northeastern Argentina. Misiones Province includes 77 protected areas $(48.5 \%$ of total area of the province) (Chebez 2005), which mostly protect the southernmost part of the Paraná Forest. Parque Provincial Moconá (Fig. 1) covers about $10 \mathrm{~km}^{2}$ of the southeastern part of the UNESCO Yabotí Biosphere Reserve (Chebez 2005), and was created to protect the Paraná Forest including the Moconá Falls Natural National Monument.

\section{SAMPLING PROCEDURE}

Two field trips were conducted, one from March 19 to 23, 2011, and another from March 31 to April 2, 2012. Samples were collected by two collectors in 2011 and three in 2012, using sweeping and beating nets. Each sample was measured by time (45'); 38 samples were taken in 2011 and 55 in 2012.

Sweeping consisted of sampling low vegetation with a $40 \mathrm{~cm}$ diameter sweep net that was emptied after a few sweeps to avoid damaging specimens. Beating consisted of sharply tapping branches or comparable vegetation with a stout stick while holding out a $90 \mathrm{~cm}$ net to catch falling insects. Beating-net size varied slightly among collectors, 


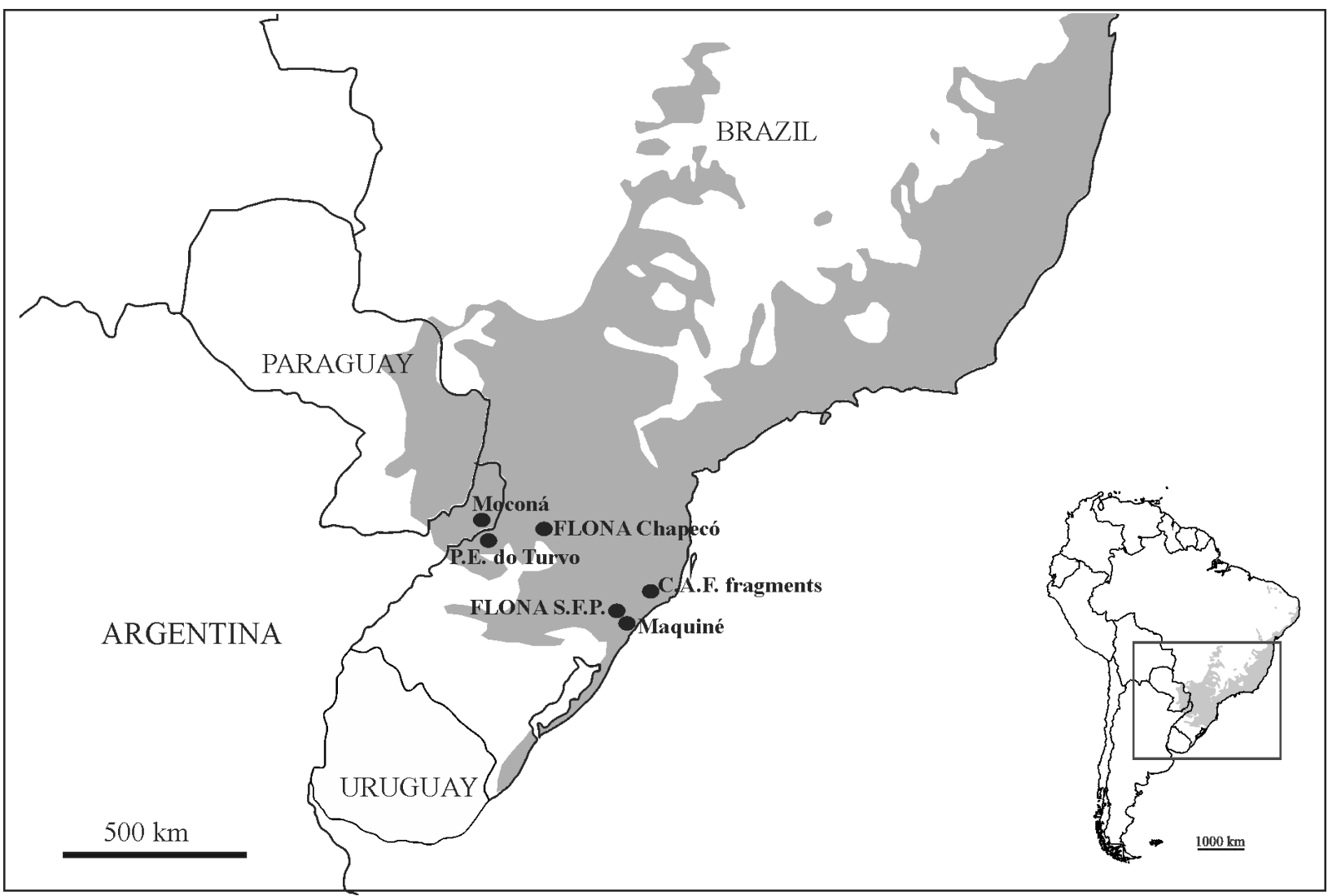

Figure 1 - Location of Parque Provincial Moconá (27 $\left.08^{\prime} \mathrm{S} / 27^{\circ} 11^{\prime} \mathrm{S}-053^{\circ} 53^{\prime} \mathrm{W} / 053^{\circ} 56^{\prime} \mathrm{W}\right)$ in Argentina, and Brazilian protected areas whose assemblages of Pentatomidae were compared. Grey area represents the original extension of the Atlantic Forest.

but because samples were defined by time, net area was probably unimportant. In addition to the taxa studied herein, all true bugs were collected.

\section{IDENTIFICATION AND CONSERVATION OF SPECIMENS}

We transferred all heteropterans from the nets to the vials by hand and using aspirators. Adults were preserved in $96 \%$ ethanol in the field, then mounted in the laboratory and examined under a Nikon SMZ 1000 stereomicroscope. All collected Heteroptera were sorted to family level; however, this study focused on four families: Pentatomidae, Coreidae, Alydidae and Rhopalidae. Whenever required to confirm identification, the genital capsule (in males) and genital segments (in females) were dissected and cleared with a saturated potassium hydroxide solution for observation; dissected genitalia were preserved in microvials with glycerin. Dr. Harry Brailovsky (UNAM, Mexico), who specializes in Coreidae, helped us with this group. All specimens were deposited in the Entomological collection at Museo de La Plata, Buenos Aires, Argentina (MLP).

\section{DATA ANALYSIS}

All the analyses were performed by family. Abundance, relative abundance, richness, singletons, doubletons, and diversity indices (Shannon-Wiener H, Simpson S, and Pielou Equitabilty J) were calculated. We also transformed the Shannon-Wiener index into the effective number of species: ${ }^{I} D=\exp (H)$ (Jost 2006).

We constructed species rarefaction curves based on accumulation of specimen richness and abundances, using EstimateS v.9.1 (Colwell and 
Elsensohn 2014). Rank-abundance curves are useful representations of assemblage structure. The number of points reveals species richness, and the order of these species in the curve indicates the relative abundance of each. The tail of the curve represents the rare species and the slope shows evenness. Rank-abundance curves were made using EstimateS v.9.1. The relative abundance of each species, on a logarithmic scale $(\log 10)$, was plotted following the rank order of the species, from most to least abundant.

We assumed that any diversity survey involves failures, whereby some species are not sampled. In order to assess the inventory completeness of our study, we consider the performance of seven richness estimators (Chao 1, Chao 2, ACE, ICE, Jackknife 1, Jackknife 2, and Bootstrap). Richness estimators were calculated for each family using EstimateS v.9.1, performing 100 randomizations in each analysis.

We compared our Pentatomidae assemblages from P. P. Moconá to assemblages from other protected areas in the Atlantic Forest: Parque Estadual do Turvo, RS, Brazil (Schmidt and Barcellos 2007), Coastal Atlantic Forest fragments, SC, Brazil (Campos et al. 2009), Floresta Nacional (FLONA) Chapecó, SC, Brazil (Bertolin et al. 2011), FLONA de Saõ Francisco de Paula and the Maquiné river basin, RS, Brazil (Bianchi et al. 2014) (Fig.1). When the species was identified only at generic level, we kept the record in the specific inventory only if the morpho-species was comparable to (presumably different from) the others inventories, e.g., a morpho-species identified at the generic level in one inventory whose genus is absent from the other inventories.

Using the richness and abundance data from each area, the Shannon-Wiener index was calculated and transformed into the effective number of species ( $\left.{ }^{1} \mathrm{D}\right)$. One advantage of expressing the diversity of each community in effective number of species is that it enables comparison of the magnitude of the difference in diversity, which is not easy to assess with the Shannon entropy index, since it is not linear (Moreno et al. 2011).

Beta diversity was measured among areas by indices that show similarity/dissimilarity between habitats in terms of species composition. We calculated the Jaccard coefficient of similarity, which describes how similar the assemblages are in terms of shared species (presence/absence), the abundance-based Morisita-Horn index, and the Abundance-based Jaccard and the Abundancebased Jaccard estimator proposed by Chao et al. (2005). The latter two reduce the undersampling bias arising from comparing two samples containing rare species or of substantially different size (Chao et al. 2005), as occurs in highly diverse areas such as the tropical forest, where many species are seldom collected and the rare species that appear in one sample are likely to be different from the rare species in other samples, even though most of them are actually present in the assemblages. The composition of pentatomids was compared among areas by cluster analysis (UPGMA), using the Abundance-based Jaccard estimator that accounts for unseen shared species (as the frequencies of the shared rare species increase, the most probable situation is that additional shared species are present in both assemblages, but absent from one or both samples) (Chao et al. 2005).

Additionally, our Coreidae assemblage was paired with the list recorded in P. E. do Turvo, RS, Brazil (Barcellos et al. 2008), and, as we did for Pentatomidae, we kept the record in the specific inventory only if the morpho-species were comparable.

\section{APPLICATION OF CONSERVATION INDICES}

The information on Pentatomidae species in each area was used to calculate the Species Conservation Importance index (SCI), the Average Species Conservation Importance (ACI) in each 
area, and then to assess the Site Conservation Values (SCV) as proposed by Halmy and Salem (2015). In order to assess the importance of the pentatomid species recorded in each area, we calculated the SCI following four criteria: rarity, geographic distribution, economic significance, and unique/shared species among assemblages, assigning a value of 2-10 to each species. The criterion rarity emphasizes how unusually a species is found within each assemblage, and is a direct extrapolation of vulnerability and need for protection; the criterion number of assemblages where the species is present assigns a higher value to those species present in fewer assemblages; the criterion geographic distribution focuses mainly in the known endemism level of each species; and for economic significance, an utilitarian value was assigned considering that the predatory Asopinae are the most valuable to protect, because they could be used as biological controllers (e.g. Podisus nigrispinus (Dallas), Supputius cincticeps (Stål)) and therefore they were assigned the maximum value. In contrast, lower values were assigned to the phytophagous species known to be harmful to agriculture (e.g. Nezara viridula (L.), Edessa meditabunda (Fab.), Dichelops furcatus (Fab.)). All criteria were equally weighted. The value of the SCI ranges from 0.1 to 1 , with higher values indicating species more valuable to conservation.

\section{RESULTS}

In the 93 samples obtained throughout the sampling period, we found 2,653 specimens distributed among 23 families of terrestrial true bugs (a partial inventory including 17 families was published by Dellapé $P$ et al. 2015). Of these, 1,027 bugs belong to the families Pentatomidae, Coreidae, Alydidae and Rhopalidae. The species of these families, with their absolute and relative abundances, are listed in Table I. Rhopalidae was the most abundant and frequent family, with a total 655 specimens distributed in $78.5 \%$ of the samples. There were 195 pentatomids in $66.7 \%$ of the samples, and 142 coreids in about $49.5 \%$ of the samples. The least abundant and frequent family was Alydidae, for which there were only 35 individuals in $20.4 \%$ of the samples (Table II).

The total number of species found was 73 . Pentatomidae was the most diverse and equitable family. We recorded 195 specimens belonging to 34 species (Fig. 2) of which 11 were singletons $(32.4 \%)$ and 6 were doubletons (17.6\%) (Table II). For this family, the dominant species were Mormidea v-luteum (Lichtenstein) and Euschistus heros (Fab.), which together accounted for 39.5\% of the sampled specimens (Fig. 3). Coreidae had intermediate richness and equitability. We recorded 142 specimens, distributed in 22 species (Fig. 2), of which 9 were singletons $(49.9 \%)$ and 2 were doubletons (9.1\%) (Table II). Cebrenis cauta Brailovsky was the dominant species, representing $38 \%$ of total coreids (Fig. 3). Alydidae and Rhopalidae were the least diverse and equitable families. We found low abundance $(\mathrm{N}=35)$ of Alydidae, represented by only six species (Fig. 2) with Stenocoris (Orizocoris) furcifera (Westwood) being highly dominant (65.7\% of the total alydids), thus contributing to the low diversity indices of this family (Table II, Fig. 3). For Rhopalidae, we recorded high abundance $(\mathrm{N}=655)$ and low diversity (11 species) (Fig. 2) with high dominance of one species, Niesthrea pictipes (Stål) (64.1\%) (Table II, Fig. 3).

The Shannon-Winner index for Pentatomidae $(\mathrm{H}=2.83)$ and Coreidae $(\mathrm{H}=2.27)$, suggested a similar trend in the distribution of dominant species. This was also partially reflected by the Simpson index $(S=9.78$ for Pentatomidae and $S=5.46$ for Coreidae). When we evaluated the distribution of abundance among the species, Pentatomidae and Coreidae had greater equitability $(\mathrm{J}=0.801$ and $\mathrm{J}=0.734$, respectively) than Rhopalidae and Alydidae ( $\mathrm{J}=0.538$ and $\mathrm{J}=0.631$, respectively) 
TABLE I

Species of Pentatomidae, Alydidae, Coreidae y Rhopalidae collected in Parque Provincial Moconá and their absolute (A. A.) and relative (R. A.) abundance.

\begin{tabular}{|c|c|c|c|c|c|}
\hline Pentatomidae & A. A. & R. A. & Coreidae & A. A. & R. A. \\
\hline Agroecus griseus Dallas & 1 & 0.513 & Acidomeria sordida (Berg) & 1 & 0.704 \\
\hline $\begin{array}{c}\text { Alveostethus pseudopolitus } \\
\text { (Ruckes) }\end{array}$ & 1 & 0.513 & Anasa varicornis (Westwood) & 11 & 7.746 \\
\hline Antiteuchus sepulcralis (Fabricius) & 2 & 1.026 & Anasa scorbutica (Fabricius) & 1 & 0.704 \\
\hline Arvelius albopunctatus (De Geer) & 1 & 0.513 & Athaumastus sp. & 3 & 2.113 \\
\hline Banasa alboapicata (Stål) & 3 & 1.538 & Camptischium clavipes (Fabricius) & 1 & 0.704 \\
\hline Chinavia impicticornis (Stål) & 2 & 1.026 & Cebrenis cauta Brailovsky & 54 & 38.028 \\
\hline Dichelops furcatus (Fabricius) & 12 & 6.154 & Cebrenis centrolineata (Westwood) & 3 & 2.113 \\
\hline Dryptocephala integra Walker & 2 & 1.026 & Cebrenis supina Brailovsky & 18 & 12.676 \\
\hline Dryptocephala lurida Erichson & 7 & 3.590 & Chariesterus cuspidatus Distant & 5 & 3.521 \\
\hline Edessa meditabunda (Fabricius) & 8 & 4.103 & Cnemomis sp. & 3 & 2.113 \\
\hline Edessa rufomarginata (De Geer) & 6 & 3.077 & Crinocerus sanctus (Fabricius) & 10 & 7.042 \\
\hline Edessa sp.3 & 4 & 2.051 & Dalmatomammurius vandoesburgi (Brailovsky) & 1 & 0.704 \\
\hline Edessa sp.4 & 2 & 1.026 & Holhymenia rubiginosa Breddin & 1 & 0.704 \\
\hline Edessa sp.5 & 1 & 0.513 & Hypselonotus fulvus var. dimidiatus (Hahn) & 2 & 1.408 \\
\hline Euschistus cornutus Dallas & 4 & 2.051 & Hypselonotus interruptus Hahn & 9 & 6.338 \\
\hline Euschistus heros (Fabricius) & 30 & 15.385 & Leptoglossus ingens (Mayr) & 1 & 0.704 \\
\hline Euschistus picticornis Stål & 3 & 1.538 & Leptoglossus neovexillatus Allen & 2 & 1.408 \\
\hline Mayrinia curvidens (Mayr) & 12 & 6.154 & Madura fusco-clavata Stål & 1 & 0.704 \\
\hline Mormidea notulifera Stål & 6 & 3.077 & Phthia lunata (Fabricius) & 6 & 4.225 \\
\hline Mormidea v-luteum (Lichtenstein) & 47 & 24.103 & Phthiacnemia picta (Drury) & 1 & 0.704 \\
\hline
\end{tabular}


TABLE I (continuation)

\begin{tabular}{|c|c|c|c|c|c|}
\hline Pentatomidae & A. A. & R. A. & Coreidae & A. A. & R.A. \\
\hline Mormidea ypsilon (Linné) & 11 & 5.641 & Piezogaster sp. & 1 & 0.704 \\
\hline Nezara viridula (Linné) & 1 & 0.513 & Zicca annulata (Burmeister) & 7 & 4.930 \\
\hline Oebalus ypsilongriseus (De Geer) & 1 & 0.513 & Rhopalidae & & \\
\hline Pallantia macula (Dallas) & 2 & 1.026 & Harmostes (Neoharmostes) apicatus Stål & 63 & 9.618 \\
\hline Piezodorus guildinii (Westwood) & 1 & 0.513 & Harmostes (Harmostes) gravidator (Fabricius) & 15 & 2.290 \\
\hline Piezodorus sp. & 1 & 0.513 & Harmostes (Harmostes) prolixus Stål & 11 & 1.679 \\
\hline Podisus nigrispinus (Dallas) & 1 & 0.513 & Harmostes (Harmostes) serratus (Fabricius) & 27 & 4.122 \\
\hline $\begin{array}{c}\text { Serdia indistincta (Fortes and } \\
\text { Grazia) }\end{array}$ & 1 & 0.513 & Harmostes (Neoharmostes) corazonus Distant & 1 & 0.153 \\
\hline Supputius cincticeps (Stål) & 1 & 0.513 & Harmostes (Neoharmostes) procerus Berg & 1 & 0.153 \\
\hline Thyanta brasiliensis Jensen-Haarup & 3 & 1.538 & Jadera aeola (Dallas) & 14 & 2.137 \\
\hline Thyanta humilis Bergroth & 7 & 3.590 & Niesthrea pictipes (Stål) & 420 & 64.122 \\
\hline Thyanta perditor (Fabricius) & 2 & 1.026 & Niesthrea similis Chopra & 12 & 1.832 \\
\hline Tylospilus armatus Thomas & 5 & 2.564 & Niesthrea vincentii (Westwood) & 82 & 12.519 \\
\hline \multirow[t]{8}{*}{ Tynacantha marginata Dallas } & 4 & 2.051 & Xenogenus picturatum Berg & 9 & 1.374 \\
\hline & & & Alydidae & & \\
\hline & & & Apidaurus conspersus Stål & 1 & 2.857 \\
\hline & & & Cydamus sp. 1 & 5 & 14.286 \\
\hline & & & Cydamus sp. 2 & 1 & 2.857 \\
\hline & & & Hyalimenus sp. & 3 & 8.571 \\
\hline & & & Stenocoris (Orizocoris) furcifera (Westwood) & 23 & 65.714 \\
\hline & & & $\begin{array}{c}\text { Stenocoris (Stenocoris) schaeferi Montemayor } \\
\text { and Dellapé }\end{array}$ & 2 & 5.714 \\
\hline
\end{tabular}




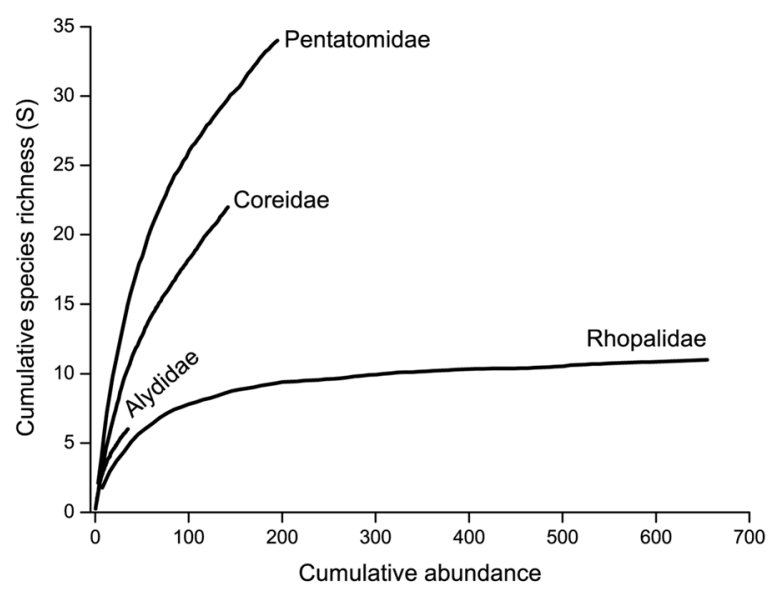

Figure 2 - Rarefaction curves showing species richness of each family studied in Parque Provincial Moconá in relation to its abundance.

(Table II). The dominant species of the latter two families were represented by nearly $65 \%$ of the collected specimens.

The overall inventory completeness of our study was $72.3 \%$. Richness estimators suggest 40 to 55 Pentatomidae species in P. P. Moconá, therefore our inventory completeness was 74\% (Fig. 4). Bootstrap and Jackknife 2 estimated the lowest and highest species richness, respectively. Despite the low richness (six species) and abundance (35 specimens) of Alydidae, richness estimators suggest that our inventory completeness was $70 \%$ (Fig. 4). Chao 1 was the most conservative estimator, suggesting a richness of 6.5 species, while Jackknife 2 indicated that Alydidae richness could be as high as 12 species. Rhopalidae was the best sampled family, with $85 \%$ mean inventory completeness (Fig. 4) and its rarefaction curves are the most asymptotic (Figs. 2, 4). The richness estimators did not differ greatly (12 to 15 species), and suggest richness similar to that currently assigned to Rhopalidae (11 species). In contrast, Coreidae was the family with greatest sampling deficit. According to the richness estimators, we should have sampled 26 to 44 species, but in fact we only found 22 , resulting in a $60 \%$ mean inventory

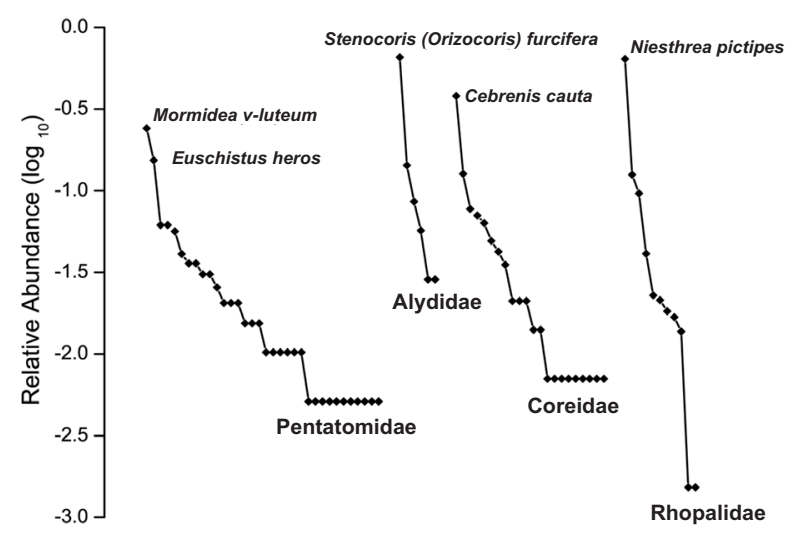

Figure 3 - Rank-abundance curves and dominant species of the bugs families studied in Parque Provincial Moconá.

completeness. The Coreidae richness estimators differed widely from each other, with Bootstrap being the most conservative, and Chao 2 estimating the greatest number of Coreidae species (Fig. 4).

When comparing the Pentatomidae assemblage from P. P. Moconá to the assemblages from the other five Atlantic Forest areas, we found that Maquiné, P. P. Moconá and the Coastal Atlantic Forest fragments had the highest diversity values, with a ${ }^{1} \mathrm{D}$ of 17.94, 17 and 15.5 species, respectively; whereas FLONA S. F. P. had the lowest ${ }^{1}$ D (Table III). We calculated the Jaccard classic based on presence/absence, the Abundance-based Jaccard, the Abundance-based Jaccard estimator, and the Morisita-Horn index, which are shown in Table IV. The first three indices show the greatest similarity between P. P. Moconá and P. E. do Turvo, and a high similarity of these two areas with FLONA Chapecó; Maquiné and the Coastal Atlantic Forest fragments, and both FLONAs also show high similarity values; the Morisita-Horn shows the highest similarity between P. P. Moconá and FLONA Chapecó, followed by P. P. Moconá and P. E. do Turvo and by Maquiné and the Coastal Atlantic Forest fragments. The dendrogram resulting from cluster analysis 


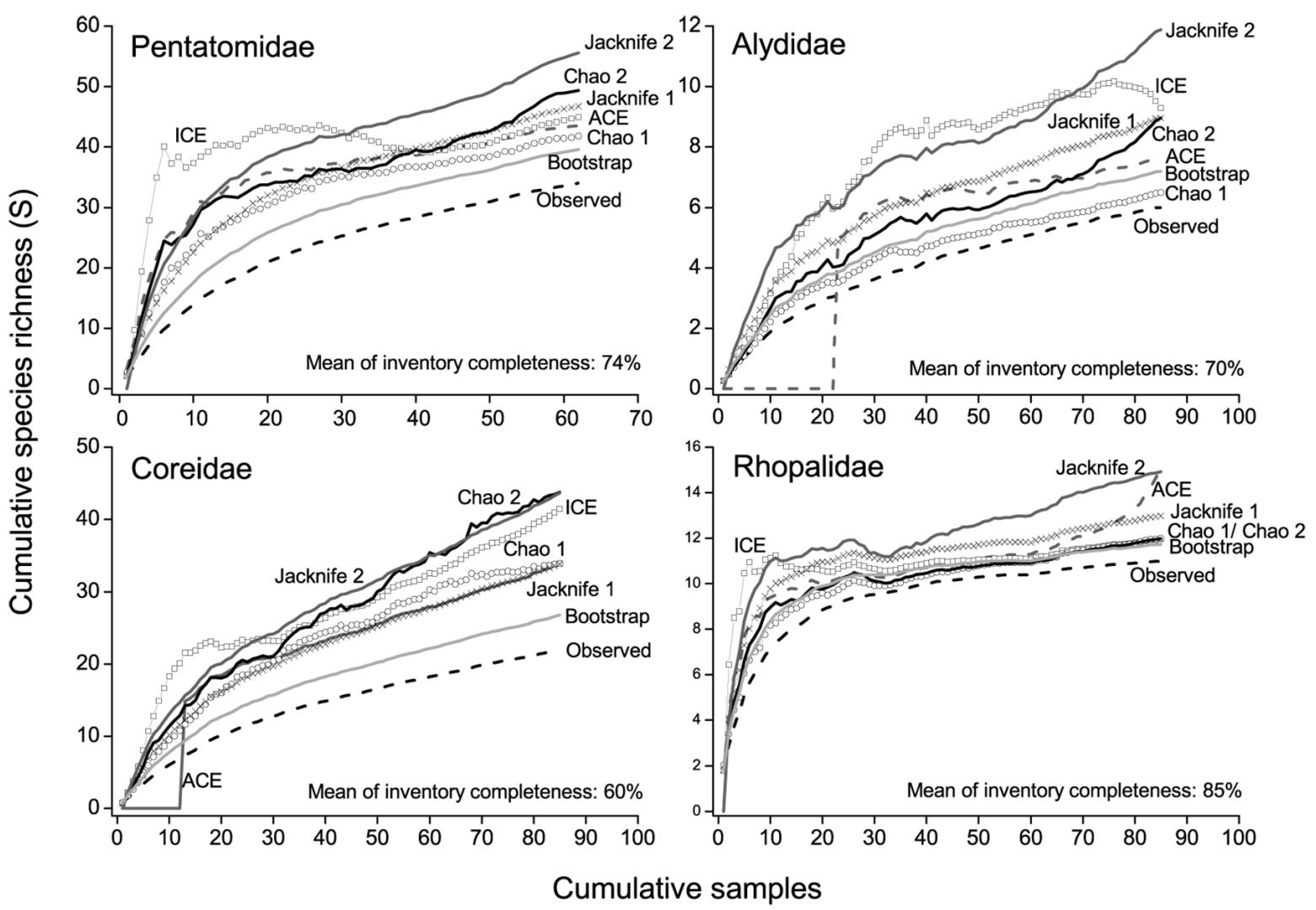

- - - Observed richness; - - - ACE; - - ICE; - O- Chao 1; —- Chao 2; $>$ Jacknife 1; —— Jacknife 2; — Bootstrap

Figure 4 - Observed richness of each bug family and the performance of seven richness estimators with relation to cumulative number of samples taken in Parque Provincial Moconá.

using UPGMA method and the Abundance-based Jaccard estimator is shown in Fig. 5.

For Coreidae, we found 22 species in P. P. Moconá, while Barcellos et al. (2008) found 19 species in P. E. do Turvo. Eight species were common to both assemblages, and the similarity indices ranged from $24 \%$ (Jaccard coefficient) to $72 \%$ (Abundance-based Jaccard estimator).

\section{SPECIES CONSERVATION IMPORTANCE INDEX AND SITE CONSERVATION VALUES}

Four criteria on Pentatomidae species in each area were applied to calculate the Species Conservation Importance index (SCI), the Average Species Conservation Importance (ACI) to each area, and then the Site Conservation Values (SCV) (Supporting Information 1). The SCV values were similar in all six areas, with higher values for FLONA S.F.P, FLONA Chapecó, and Maquiné as shown in Table $\mathrm{V}$.

In P. P. Moconá, the species importance assessed based on the SCI index shows that pentatomids ranged from low $(\mathrm{SCI}=0.3)$ to high importance $(\mathrm{SCI}=0.85)$. Six species were classified as having low importance ( $\mathrm{SCI} \leq 0.5), 17$ species as moderate to high importance (SCI ranging from 0.51 to 0.75 ), and 8 species as high importance ( $\mathrm{SCI}>0.76$ ). The species having high conservation importance index are Alveostethus pseudopolitus (Ruckes), Antiteuchus sepulcralis (Fab.), Dryptocephala integra Walker (Discocephalinae), Agroecus griseus Dallas, Serdia indistincta Fortes and Grazia (Pentatominae), Supputius cinctipes 
TABLE II

Inventory data and diversity indices comparing the four families studied in Parque Provincial Moconá.

\begin{tabular}{ccccc}
\hline & Pentatomidae & Alydidae & Coreidae & Rhopalidae \\
\hline Abundance & 195 & 35 & 142 & 655 \\
Observed Richness & 34 & 6 & 22 & 11 \\
Singletons & 11 & 2 & 9 & 2 \\
Doubletons & 6 & 1 & 2 & 0 \\
Diversity indices & & & 2.27 & 1.29 \\
Shannon-Winner $(\mathrm{H})$ & 2.83 & 1.13 & 5.46 & 2.27 \\
Simpson (S) & 9.78 & 2.15 & 0.734 & 0.538 \\
Pielou Equitability $(\mathrm{J})$ & 0.801 & 0.631 & 9.7 & 3.6 \\
Effective sp. number $\left({ }^{1} \mathrm{D}\right)$ & 17 & 3 & & \\
\hline
\end{tabular}

TABLE III

Inventory data and diversity indices of Pentatomidae comparing six protected areas in the Atlantic Forest (Between brackets the number of species used to calculated de SCI, ACI and SCV).

\begin{tabular}{ccccccc}
\hline & P. P. Moconá & P. E. do Turvo & $\begin{array}{c}\text { FLONA } \\
\text { Chapecó }\end{array}$ & $\begin{array}{c}\text { C. A. F. } \\
\text { fragments }\end{array}$ & $\begin{array}{c}\text { Maquiné } \\
\text { FLONA } \\
\text { S. F. P. }\end{array}$ \\
\hline Abundance & 188 & 651 & 143 & 492 & 126 & 535 \\
Observed Richness & $34(31)$ & $40(33)$ & $30(24)$ & $37(36)$ & $31(24)$ & $27(23)$ \\
Singletons & 11 & 11 & 10 & 12 & 11 & 5 \\
Doubletons & 6 & 7 & 8 & 2 & 7 & 4 \\
Diversity indices & & & & 2.74 & 2.89 & 1.87 \\
Shannon-Winner $(\mathrm{H})$ & 2.83 & 2.34 & 2.22 & 15.54 & 17.94 & 6.49 \\
Effective sp. number $\left({ }^{1} \mathrm{D}\right)$ & 17 & 10.4 & 9.25 & & \\
\hline
\end{tabular}

TABLE IV

Similarity indices based on presence/absence and abundance data of pentatomids as a measure of beta diversity among six sites of the Atlantic Forest.

\begin{tabular}{ccccc}
\hline & Jaccard Classic & $\begin{array}{c}\text { Abundance-based } \\
\text { Jaccard }\end{array}$ & $\begin{array}{c}\text { Abundance-based } \\
\text { Jaccard estimator }\end{array}$ & $\begin{array}{c}\text { Morisita- } \\
\text { Horn }\end{array}$ \\
\hline $\begin{array}{c}\text { P. P. Moconá - } \\
\text { P. E. do Turvo }\end{array}$ & 0.413 & 0.768 & 0.855 & 0.471 \\
$\begin{array}{c}\text { P. P. Moconá - } \\
\text { FLONA Chapecó } \\
\text { P. P. Moconá - }\end{array}$ & 0.196 & 0.48 & 0.522 & 0.731 \\
$\begin{array}{c}\text { C.A.F. fragments } \\
\text { P. P. Moconá - }\end{array}$ & 0.193 & 0.372 & 0.479 & 0.233 \\
Maquiné & 0.17 & 0.287 & 0.319 & 0.165 \\
$\begin{array}{c}\text { P. P. Moconá - } \\
\text { FLONA S. F. P. }\end{array}$ & 0.058 & 0.054 & 0.054 & 0.02 \\
$\begin{array}{c}\text { P. E. do Turvo - } \\
\text { FLONA Chapecó }\end{array}$ & 0.208 & 0.511 & 0.607 & 0.072 \\
\hline
\end{tabular}


TABLE IV (continuation)

\begin{tabular}{|c|c|c|c|c|}
\hline & Jaccard Classic & $\begin{array}{c}\text { Abundance-based } \\
\text { Jaccard }\end{array}$ & $\begin{array}{l}\text { Abundance-based } \\
\text { Jaccard estimator }\end{array}$ & $\begin{array}{c}\text { Morisita- } \\
\text { Horn }\end{array}$ \\
\hline $\begin{array}{l}\text { P. E. do Turvo - } \\
\text { C.A.F. fragments }\end{array}$ & 0.164 & 0.264 & 0.278 & 0.046 \\
\hline $\begin{array}{l}\text { P. E. do Turvo - } \\
\text { Maquiné- }\end{array}$ & 0.16 & 0.075 & 0.089 & 0.029 \\
\hline $\begin{array}{l}\text { P. E. do Turvo - } \\
\text { FLONA S. F. P. }\end{array}$ & 0.094 & 0.043 & 0.043 & 0.005 \\
\hline $\begin{array}{l}\text { FLONA Chapecó - } \\
\text { C.A.F. fragments }\end{array}$ & 0.22 & 0.466 & 0.482 & 0.288 \\
\hline $\begin{array}{c}\text { FLONA Chapecó - } \\
\text { Maquiné }\end{array}$ & 0.171 & 0.344 & 0.36 & 0.209 \\
\hline $\begin{array}{l}\text { FLONA Chapecó - } \\
\text { FLONA S. F. P. }\end{array}$ & 0.2 & 0.487 & 0.491 & 0.081 \\
\hline $\begin{array}{l}\text { C. A. F. fragments - } \\
\text { Maquiné }\end{array}$ & 0.245 & 0.347 & 0.405 & 0.343 \\
\hline $\begin{array}{l}\text { C. A. F. fragments - } \\
\text { FLONA S. F. P. }\end{array}$ & 0.13 & 0.078 & 0.092 & 0.025 \\
\hline $\begin{array}{c}\text { Maquiné - } \\
\text { FLONA S. F. P. }\end{array}$ & 0.171 & 0.317 & 0.318 & 0.306 \\
\hline
\end{tabular}

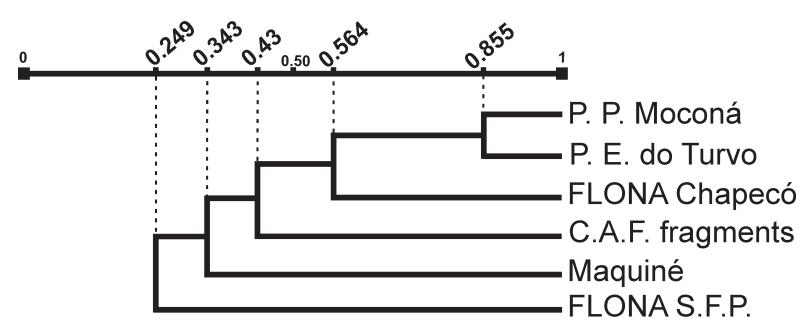

Figure 5 - Dendrogram resulting from cluster analysis with UPGMA method using the Abundance-based Jaccard estimator of Pentatomidae species.

(Stål), Tylospilus armatus Thomas, and Tynacantha marginata Dallas (Asopinae).

\section{DISCUSSION}

The greater richness and diversity of Pentatomidae in relation to the other families studied was expected, since it is one of the largest Heteroptera families, comprising 760 genera and over 4,000 species worldwide, with about 250 species in Argentina (Grazia and Schwertner 2008, Dellapé G et al. 2015).
Although Coreidae was the second most diverse family, it also had the highest sampling deficit, highest percentage of singletons, and lowest inventory completeness, probably due to a failure in the sampling procedure to catch arboreal elements. Barcellos et al. (2008) found a similar situation upon studying the Coreoidea of P. E. do Turvo and stated that some of the rare species collected represent species whose habitats are not accessible using the beating net method, as is the case of coreoid inhabitants of the forest canopy. The family Rhopalidae was the best sampled, with $85 \%$ mean inventory completeness and asymptotic rarefaction curves that show a high efficiency of sweeping and beating methods to collect these phytophagous bugs that live in herbs and woody plants. Of the four families, Rhopalidae had the lowest effective number of species because of the high dominance of one species, and in addition, 
TABLE V

Average Species Conservation Importance and Site Conservation Value for each area, based on the four criteria established on pentatomids species: rarity, geographic distribution, economic significance and number of assemblage where the species is present.

\begin{tabular}{ccccccc}
\hline & Moconá & P. E. do Turvo & $\begin{array}{c}\text { FLONA } \\
\text { Chapecó }\end{array}$ & $\begin{array}{c}\text { C. A. F. } \\
\text { fragments }\end{array}$ & $\begin{array}{c}\text { Maquiné } \\
\text { FLONA } \\
\text { S. F. P. }\end{array}$ \\
\hline $\begin{array}{c}\text { Average Species } \\
\text { Conservation Importance } \\
\text { Site Conservation Value }\end{array}$ & 0.64 & 0.68 & 0.68 & 0.69 & 0.68 & 0.75 \\
\hline
\end{tabular}

the low percentage of singletons brought down the diversity indices of the family.

The P. P. Moconá and P. E. do Turvo are located in the Paraná Forest, the Coastal Atlantic Forest fragments and Maquiné in the Serra do Mar Coastal Forest, and both FLONAs are also in the same ecoregion, Araucaria Moist Forest (according to Di Bitetti et al. 2003). We expected that, when comparing the pentatomid fauna among the six areas, these couples of areas show highest similarity values; but this was only evident between P. P. Moconá and P. E. do Turvo. FLONA S. F. P. is the most dissimilar area as showed by the low indices values when compared with the other areas, obtaining its highest values when compared with FLONA Chapecó and with Maquiné. This last area is the nearest to FLONA S. F. P. showing that the geographic proximity is also strongly conditioning the diversity.

The dendrogram resulting from cluster analysis showed high similarity between P. P. Moconá and P. E. do Turvo, whose assemblages shared 19 Pentatomidae species, with similarity of indices from over $40 \%$ to over $85 \%$. This high similarity is consistent with the proximity of the two areas, which are only separated by the Uruguay River. In agreement with the geographical distance among the studied assemblages (Fig. 1), these two sites also had higher similarity to FLONA Chapecó than with the other three areas: the Coastal Atlantic Forest fragments, Maquiné and FLONA S. F. P., which are sequentially added to the dendrogram.
The low number of shared Coreidae species in P. P. Moconá and P. E. do Turvo assemblages (about $39 \%$ of the species) resulted in a low similarity coefficient between these areas, and may indicate either a real difference between assemblages or low inventory completeness. The second hypothesis is consistent with our results for richness estimators in P. P. Moconá, which showed the family Coreidae as the group with the greatest sampling deficit.

After the application of the SCI as a basis for assessing conservation value of areas (SCV), we found similar values in P. P. Moconá, P. E. do Turvo, and the Coastal Atlantic Forest fragments and higher values in Maquiné, FLONA Chapecó and FLONA S. F. P. This last area presented almost half of the unshared inventoried species, and several with a restricted known geographic distribution obtaining the highest value.

The FLONAs are conservation units with multiple sustainable uses of forest resources, promoting natural resource management with emphasis on timber production; they are composed of natural forest and Pinus, Eucalyptus, Araucaria and Ilex plantations together with native vegetation (Bonatti et al. 2006, Bertolin et al. 2011). The partial modification of these areas may affect species extinction locally, but the emergence of different environmental conditions (high heterogeneity) may increase the degree of replacement (Halffter 1998), also favoring the ingress of foreign faunal components. 
The three areas with the highest SCV values presented the lowest number of species (23-24), which may be explained by the methodology used to calculate it. SCV is normalized by the number of species recorded in each area, so a higher number of species does not necessarily indicate higher conservation value (Halmy and Salem 2015).

Because of the high diversity and abundance of insects in tropical forests (and in most of the environments on Earth) they should be taken into account to evaluate conservation units. However there is no information about vulnerability or ecological role for the vast majority of species. Many species are known from a few specimens and their distributional range is recovered from a few records. These information gaps limit the application of criteria for evaluating the importance of the species and thereby assigning conservation values to areas they inhabit.

We applied for the first time the SCI and SCV indices to a relatively well known family of Heteroptera from the Atlantic Forest. Increased knowledge about the taxonomy, biogeography and ecology of this group, or others insect taxa, will allow to expand the criteria used and the application of multiple indices which will enhance the capacity to assess the importance of conservation of unprotected areas.

This work represents the first contribution to the knowledge of the diversity and assemblage structure of two large groups of Neotropical true bugs in a protected area of the Argentinean Atlantic Forest, and the first time that indices have been applied to weight the conservation value of Heteroptera species and of the protected areas.

\section{ACKNOWLEDGMENTS}

We thank the Misiones Province park rangers for their assistance during the collecting trips. This study was supported by the Consejo Nacional de Investigaciones Científicas y Técnicas
(CONICET), Argentina, and the following grants: PIP 0255 (2010- 2012), PIP 0249 (2013- 2015) and UNLP N/664.

\section{REFERENCES}

BARCELLOS A, SCHMIDT LS AND BRAILOVSKY H. 2008. Abundance and species richness of Coreoidea (Hemiptera: Heteroptera) from Parque Estadual do Turvo, southern Brazil. Neotrop Entomol 37: 406-412.

BERTOLIN TB, BALDO FV, GARBELOTTO TA, CAMPOS LA AND GARCIA FRM. 2011. Percevejos de Plantas. In: Garcia FRM, Lutinski JA and Lutinski CJ (Eds), Biodiversidade da Floresta Nacional de Chapecó, São Paulo: Baraúna, p. 91-116.

BIANCHI FM, MENDONCA JR. MS AND CAMPOS LA. 2014. Comparing Vegetation Types and Anthropic Disturbance Levels in the Atlantic Forest: How Do Pentatomoidea (Hemiptera: Heteroptera) Assemblages Respond? Environ Entomol 43: 1507-1513.

BONATTI J, MARCZWSKI M, REBELATO GS, SILVEIRA CF, CAMPELLO FD, RODRIGUES G, GUERRA T AND HARTZ SM. 2006. Trilhas da Floresta Nacional de São Francisco de Paula, Rio Grande do Sul, Brasil: Mapeamento, Análise e Estudo da Capacidade de Carga Turística. Rev Bras Bioci 4: 15-26.

CAMPOS LA, BERTOLIN TB, TEIXEIRA RA AND MARTINS FS. 2009. Diversidade de Pentatomoidea (Hemiptera, Heteroptera) em três fragmentos de Mata Atlântica no sul de Santa Catarina. Iheringia, Sér Zool 99: 165-171.

CAMPOS RE, SPINELLI G AND MOGI M. 2011. Culicidae and Ceratopogonidae (Diptera: Nematocera) inhabiting phytotelmata in Iguazú National Park, Misiones Province, subtropical Argentina. Rev Soc Entomol Arg 70: 111-118.

CHAO A, CHAZDON RL, COLWELL RK AND TSUNGJEN S. 2005. A new statistical approach for assessing similarity of species composition with incidence and abundance data. Ecology Lett 8: 148-159.

CHEBEZ JC. 2005. Guía de las Reservas Naturales de la Argentina. Nordeste. Buenos Aires: Albatros, 288 p.

CHEBEZ JC AND HILGERT N. 2003. Brief history of conservation in the Paraná Forest. In: Galindo-Leal C and Câmara IG (Eds), Atlantic Forest of the South America. Biodiversity status, threats, and outlook, Washington DC: Center for Applied Biodiversity Science at Conservation International, Island Press, p. 141-159.

COLWELL RK AND ELSENSOHN JE. 2014. EstimateS turns 20: statistical estimation of species richness and shared species from samples, with non-parametric extrapolation. Ecography 37: 609-613. 
CULLEN L JR, BODMER RE AND VALLADARES-PÁDUA C. 2001. Ecological consequences of hunting in Atlantic Forest patches, São Paulo, Brazil. Oryx 35: 137-144.

DELLAPÉ G, RIDER DA AND DELLAPÉ PM. 2015. Notes on distributions for Argentinean Pentatomidae (Heteroptera: Pentatomoidea), with new records in the country. Rev Bras Entomol 59: 169-176.

DELLAPÉ PM, MELO MC, MONTEMAYOR SI, DELLAPÉ G AND BRAILOVSKY H. 2015. Terrestrial Heteroptera (Hemiptera) from Parque Provincial Moconá (Misiones, Argentina). Check List 11(1662): 1-18.

DI BITETTI MS, PLACCI G AND DIETZ LA. 2003. A biodiversity vision for the Upper Paraná Atlantic Forest eco-region: designing a biodiversity conservation landscape and setting priorities for conservation action. Washington DC: World Wildlife Fund, 104 p.

GALINDO-LEAL C AND CÂMARA IG. 2003. Atlantic Forest hotspot status: an overview. In: Galindo-Leal $\mathrm{C}$ and Câmara IG (Eds), Atlantic Forest of the South America. Biodiversity status, threats, and outlook, Washington DC: Center for Applied Biodiversity Science at Conservation International, Island Press, p. 3-11.

GIRAUDO AR, POVEDANO H, BELGRANO MJ, KRAUCZUK E, PARDIÑAS U, MIQUELARENA A, LIGIER D, BALDO D AND CASTELINO M. 2003. Biodiversity status of the Interior Atlantic Forest of Argentina. In: Galindo-Leal C and Câmara IG (Eds), Atlantic Forest of the South America. Biodiversity status, threats, and outlook, Washington DC: Center for Applied Biodiversity Science at Conservation International, Island Press, p. 160-180.

GIRAUDO AR, MATTEUCCI SD, ALONSO J, HERRERA J AND ABRAMSON RR. 2008. Comparing bird assemblages in large and small fragments of the Atlantic Forest hotspots. Biodivers Conserv 17: 1251-1265.

GRAZIA J AND SCHWERTNER CF. 2008. Pentatomidae e Cyrtocoridae. In: Claps LE, Debandi G and Roig-Juñent S (Eds), Biodiversidad de Artrópodos Argentinos, Mendoza: Sociedad Entomológica Argentina, p. 223-234.

HALFFTER G. 1998. A strategy for measuring landscape biodiversity. Biol Int 36: 3-17.
HALMY MWAAND SALEM BB. 2015. Species conservation importance index (SCI) for comparing sites' conservation value at landscape level. Rev Bras Bot 38: 823-835.

JOST L. 2006. Entropy and diversity. Oikos 113: 363-375.

LEWIS OT AND BASSET Y. 2007. Insect Conservation in Tropical Forests. In: Stewart AJA, New TR and Lewis OT (Eds), Insect Conservation Biology, Wallingford: The Royal Entomological Society and CABI, p. 34-56.

MANZO V, ROMERO F, RUEDA MARTIN P, MOLINERI C, NIETO C, RODRIGUEZ J AND DOMINGUEZ E. 2014. Insectos acuáticos del Parque Provincial Urugua-í, Misiones, Argentina. Rev Soc Entomol Arg 73: 155-170.

MAZZUCCONI SA, LÓPEZ-RUF M AND BACHMANN AO. 2009. Gerromorpha y Nepomorpha (Insecta: Heteroptera) del Parque Provincial Salto Encantado del Valle del Cuñá Pirú, Provincia de Misiones, Argentina. Lundiana 9: 57-66.

MITTERMEIER RA, ROBLES GIL P, HOFFMAN M, PILGRIM J, BROOKS T, MITTERMEIER CG, LAMOREUX J AND DA FONSECA GAB. 2004. Hotspots revisited: Earth's biologically richest and most endangered ecoregions. Mexico City: CEMEX, 390 p.

MORENO CE, BARRAGÁN F, PINEDA E AND PAVÓN NP. 2011. Reanálisis de la diversidad alfa: alternativas para interpretar y comparar información sobre comunidades ecológicas. Rev Mex Biodivers 82: 1249-1261.

MYERS N, MITTERMEIER RA, MITTERMEIER CG, FONSECA GA AND KENT J. 2000. Biodiversity hotspots for conservation priorities. Nature 403: 853-858.

NEW TR. 2012. Introduction to insect conservation, an emerging discipline. In: New TR (Ed), Insect conservation: past, present and prospects. Dordrecht: Springer, p. 1-17.

SCHMIDT LS AND BARCELLOS A. 2007. Abundancia e riqueza de especies de Heteroptera (Hemiptera) do Parque Estadual do Turvo, sur do Brasil: Pentatomoidea. Iheringia, Sér Zool 97: 73-79.

TABARELLI M, VENCESLAU AGUIAR A, CEZAR RIBEIRO M, METZGER JP AND PERES CA. 2010. Prospects for biodiversity conservation in the Atlantic Forest: Lessons from aging human-modified landscapes. Biol Conserv 143: 2328-2340. 